\title{
Chapter 17 \\ The Role of Farmers' Entrepreneurial Orientation on Agricultural Innovations in Ugandan Multi-Stakeholder Platform
}

\author{
Carlos Luis Barzola Iza, Domenico Dentoni, Martina Mordini, \\ Prossy Isubikalu, Judith Beatrice Auma Oduol, and Onno Omta
}

\subsection{Introduction}

This chapter examines entrepreneurship as part of the broad debate surrounding when and why farmers adopt agricultural innovations, especially in the context of multi-stakeholder platforms (MSPs) (Kilelu et al. 2013; Schut et al. 2015) and similar organizations seeking to scale climate-smart agriculture (CSA) practices. Farmer entrepreneurship generally refers to a process of recombining agricultural resources innovatively to create opportunities for value creation (Shane and Venkataraman 2000; Lans et al. 2013). Entrepreneurial farmers may be among the first in a community to experiment with new practices, mobilize a previously underutilized resource, or use fresh information to build a new market for agricultural products. Such skills will be particularly crucial in the coming decades, as climate change forces farmers to adapt their agricultural systems. Recent investigations suggest that entrepreneurship may help agents respond to environmental shocks or adapt to rapidly changing market and conditions (Naudé 2010; York and Venkataraman 2010; Bruton et al. 2008; Khavul and Bruton 2013; Bruton et al. 2013). This literature,

\footnotetext{
C. L. Barzola Iza $(\bowtie)$

Business Management and Organisation (BMO), Wageningen University, Hollandseweg 1, Wageningen, 6706 KN, The Netherlands

Facultad de Ciencias de la Vida (FCV), Escuela Superior Politecnica del Litoral (ESPOL), Campus Gustavo Galindo, Km 30.5 Via perimetral, Guayaquil, Ecuador e-mail: carlos.barzolaiza@wur.nl

D. Dentoni · M. Mordini · O. Omta

Business Management and Organisation (BMO), Wageningen University, Hollandseweg 1, Wageningen, 6706 KN, The Netherlands

P. Isubikalu

College of Agricultural and Environmental Science, Makerere University, Kampala, Uganda

J. B. Auma Oduol

World Agroforestry Center (ICRAF), Nairobi, Kenya
}

T. S. Rosenstock et al. (eds.), The Climate-Smart Agriculture Papers, https://doi.org/10.1007/978-3-319-92798-5_17 
however, is largely lacking in empirical evidence. Similarly, the burgeoning literature that analyzes the adoption of CSA-related innovations (Lipper et al. 2014; Zilberman et al. 2018) has not yet considered farmer entrepreneurship as a significant influence on such processes.

Our study seeks to fill this gap in the literature by collecting evidence on the relationship between entrepreneurial mindsets and an openness to agricultural innovation. To explore why certain farmers innovate and adapt, this chapter (i) proposes an adapted measurement model for farmer entrepreneurship, and (ii) investigates quantitatively the influence of farmer entrepreneurship and farm characteristics on three types of innovation: "product innovation," which here refers to the use of new farm inputs, transformation of farm output into new products, or production according to a new quality standard; "process innovation," which involves adopting new farm practices, embracing new ways of farm organization, or putting new information into use; and "market innovation," which entails opening a new market channel.

We ground our study in interviews with farmers associated with Ugandan MSPs involved in coffee and honey value chains. Recently, MSPs have attempted to introduce CSA practices not only in coffee and honey but also in other sectors (Bomuhangi et al. 2016; Sabiiti et al. 2016). This study has implications for agents in MSPsfarmers and their representatives, researchers, value-chain partners and policymakers - or similar multi-actor organizations who wish to promote the adoption of CSA or other novel practices. By understanding and encouraging farmer entrepreneurship, MSPs may be able to stimulate a broad range of agricultural innovation.

\subsection{Methods}

For this study, a survey questionnaire was completed by 152 farmers in four sub-counties (Mukoto, Namabya, Bukhofu and Namboko) of Uganda's Manafwa district. The questionnaire covered the farm's characteristics and the farmers' entrepreneurial orientation. Farm characteristics included demographics (age, gender, education), farm size and access to resources (both tangible resources such as credit, fertilizers, etc. and intangible resources such as intellectual capital). To assess farmer entrepreneurship, we selected four key dimensions of entrepreneurial orientation: innovativeness, risk-taking, proactiveness and entrepreneurial intentions. Finally, farmers' innovation was measured in line with the empirical analyses by (Wu and Pretty 2004) on product innovation, (Yang 2013) on process innovation, and (Johne 1999) on market innovation (see Table 17.1). All questionnaire items were organized on a 5-point Likert scale.

As a first step, a confirmatory factor analysis (CFA) was performed. This allows one to assess whether a measurement model for a latent or intangible variable (such as entrepreneurial orientation) is appropriately reflected by a questionnaire (Harrington 2009). The following indices help in this assessment: chi-squared test, the root mean square error of approximation (RMSEA), goodness of fit index (GFI) and the comparative fix index (CFI). The CFA confirmed that slightly adapted measures of innovativeness, proactiveness and entrepreneurial intentions suited the 
Table 17.1 Operationalization of concepts: entrepreneurial competences and farmer characteristics

\begin{tabular}{|c|c|c|}
\hline Measure & Literature & Questionnaire item \\
\hline \multicolumn{3}{|c|}{ Entrepreneurial competences } \\
\hline \multirow[t]{4}{*}{ Innovativeness } & \multirow{4}{*}{$\begin{array}{l}\text { "Entrepreneurial orientation: a psychological } \\
\text { model of success among southern African } \\
\text { small business owners" (Krauss et al. 2005), } \\
\text { "Adapting the measurement of youth } \\
\text { entrepreneurship potential to the context of } \\
\text { Mindanao, Philippines" Lai et al. (2017a, b) }\end{array}$} & $\begin{array}{l}\text { I always like to search for the } \\
\text { latest information and } \\
\text { technology }\end{array}$ \\
\hline & & $\begin{array}{l}\text { I like to try new technology in } \\
\text { my farm }\end{array}$ \\
\hline & & $\begin{array}{l}\text { If there is an improvement in } \\
\text { my coffee/honey product, I } \\
\text { am willing to change where I } \\
\text { sell it }\end{array}$ \\
\hline & & $\begin{array}{l}\text { I am willing to include new } \\
\text { high-yielding varieties/more } \\
\text { bee hives in my farm, to } \\
\text { satisfy more customers }\end{array}$ \\
\hline \multirow[t]{4}{*}{ Risk-taking } & \multirow{4}{*}{$\begin{array}{l}\text { "Entrepreneurial orientation: a psychological } \\
\text { model of success among southern African } \\
\text { small business owners" (Krauss et al. } \\
\text { 2005)"Adapting the measurement of youth } \\
\text { entrepreneurship potential to the context of } \\
\text { Mindanao, Philippines" Lai et al. }(2017 \mathrm{a}, \mathrm{b})\end{array}$} & $\begin{array}{l}\text { I would keep my current } \\
\text { varieties/bee hives in the farm, } \\
\text { rather than substituting them } \\
\text { with others that I do not know }\end{array}$ \\
\hline & & $\begin{array}{l}\text { I prefer avoiding doing an } \\
\text { investment in my farm, if I do } \\
\text { not know the benefits that I } \\
\text { will get }\end{array}$ \\
\hline & & $\begin{array}{l}\text { I do not want to enlarge my } \\
\text { farm, because I do not want to } \\
\text { incur more costs }\end{array}$ \\
\hline & & $\begin{array}{l}\text { If someone suggests me to } \\
\text { include more high-yielding } \\
\text { varieties/bee hives in my } \\
\text { farm, I will do it and I take } \\
\text { great risk (chances for very } \\
\text { high profits) }\end{array}$ \\
\hline \multirow[t]{4}{*}{ Proactiveness } & \multirow{4}{*}{$\begin{array}{l}\text { "Entrepreneurial orientation: a psychological } \\
\text { model of success among southern African } \\
\text { small business owners" (Krauss et al. 2005), } \\
\text { "Adapting the measurement of youth } \\
\text { entrepreneurship potential to the context of } \\
\text { Mindanao, Philippines" Lai et al. (2017a, b) }\end{array}$} & $\begin{array}{l}\text { I am willing to start practices } \\
\text { that other farms do not do yet }\end{array}$ \\
\hline & & $\begin{array}{l}\text { If asked to adopt another type } \\
\text { of farming technology, I am } \\
\text { one of the first farmers to use } \\
\text { it }\end{array}$ \\
\hline & & $\begin{array}{l}\text { For my job, I perform above } \\
\text { and beyond expectations, but } \\
\text { there is always something } \\
\text { more to be done or improved }\end{array}$ \\
\hline & & $\begin{array}{l}\text { I do not mind failing if I learn } \\
\text { something different from } \\
\text { another coffee/honey farming } \\
\text { practice }\end{array}$ \\
\hline
\end{tabular}


Table 17.1 (continued)

\begin{tabular}{|c|c|c|}
\hline Measure & Literature & Questionnaire item \\
\hline \multirow[t]{4}{*}{ Intentions } & \multirow[t]{4}{*}{$\begin{array}{l}\text { "Social structure, reasonable gain, and } \\
\text { entrepreneurship in Africa" (George et al. } \\
\text { 2016) }\end{array}$} & $\begin{array}{l}\text { I intend to start a new } \\
\text { coffee-honey-related business } \\
\text { in the next } 3 \text { years (i.e. } \\
\text { trading, processing) }\end{array}$ \\
\hline & & $\begin{array}{l}\text { I intend to include a new } \\
\text { technology to increase the } \\
\text { yield of my coffee/honey } \\
\text { productions in the next } \\
3 \text { years }\end{array}$ \\
\hline & & $\begin{array}{l}\text { I intend to expand the contacts } \\
\text { with other actors in my value } \\
\text { chain in the next } 3 \text { years }\end{array}$ \\
\hline & & $\begin{array}{l}\text { With my credit and savings, I } \\
\text { intend to enlarge my farm } \\
\text { with only coffee/honey } \\
\text { production in the next } 3 \text { years }\end{array}$ \\
\hline \multicolumn{3}{|c|}{ Farmers innovation } \\
\hline $\begin{array}{l}\text { Product } \\
\text { innovation }\end{array}$ & $\begin{array}{l}\text { "Social connectedness in marginal rural } \\
\text { China: The case of farmer innovation circles } \\
\text { in Zhidan, north Shaanxi" (Wu and Pretty } \\
\text { 2004) }\end{array}$ & $\begin{array}{l}\text { I have improved the use of my } \\
\text { production practices in my } \\
\text { coffee/honey farm to improve } \\
\text { the quality of my coffee/ } \\
\text { honey, in the past } 5 \text { years }\end{array}$ \\
\hline $\begin{array}{l}\text { Process } \\
\text { innovation }\end{array}$ & $\begin{array}{l}\text { "An empirical research on farmer innovation } \\
\text { in agriculture industrial clusters" (Yang 2013) }\end{array}$ & $\begin{array}{l}\text { I have improved my } \\
\text { production practices, because } \\
\text { other fellow farmers } \\
\text { suggested it to me, in the past } \\
5 \text { years }\end{array}$ \\
\hline $\begin{array}{l}\text { Process } \\
\text { innovation }\end{array}$ & $\begin{array}{l}\text { "An empirical research on farmer innovation } \\
\text { in agriculture industrial clusters" (Yang 2013) }\end{array}$ & $\begin{array}{l}\text { I have improved my } \\
\text { production practices, because } \\
\text { other actors in my value chain } \\
\text { suggested it to me, in the past } \\
5 \text { years }\end{array}$ \\
\hline $\begin{array}{l}\text { Market } \\
\text { innovation }\end{array}$ & "Successful market innovation" (Johne 1999) & $\begin{array}{l}\text { I have changed where I sell } \\
\text { my coffee/honey production } \\
\text { in the past } 5 \text { years }\end{array}$ \\
\hline
\end{tabular}


Ugandan context. However, the measures of risk-taking were not sufficiently well fitted to this context. After minor adaptations to the initial measurement model, ${ }^{1}$ the index values were the following 2 GFI $=0.941$, AGFI $=0.9$, RMSEA $=0.055$, $\mathrm{CFI}=0.933$; chi square $\mathrm{p}$-value $=0.05$. This shows that the measurement model of entrepreneurial orientation fitted well with the Ugandan context.

After performing the CFA, linear regressions were used to analyze the impact of entrepreneurial orientation on product, process and market innovations, in interaction with farm characteristics. Multiple regression models were run using different interaction terms (e.g., the combined effect of innovativeness and education level, or the combined effect of proactiveness and age) in order to: (i) understand whether, when considering different control and interaction variables, the effects on agricultural innovations were stable; and (ii) assess whether the effect of entrepreneurial orientation and farm characteristics vary in their impact on innovation in general as well as on specific types of innovation.

\subsection{Findings}

Figure 17.1 shows the key tested relationships among the variables of interest: entrepreneurial orientation, farm characteristics and farmer innovations. In the first tested regression model (when farm characteristics and entrepreneurial orientation are considered together with interaction terms), it was found that only education

\footnotetext{
${ }^{1}$ Different combinations have been created between the different first-order latent constructs. While running the analysis, problems emerge if risk-taking is included amongst the latent constructs. If risk-taking is included the values are represented as follows: $\mathrm{GFI}=0.855, \mathrm{AGFI}=0.803$, $\mathrm{RMSEA}=0.084, \mathrm{CFI}=0.661$, and the chi square is significant $(\mathrm{p}$ value $=0.000$ ). Problems also arises whether a CFA is performed for the first-order latent construct risk-taking, when taken alone, thus without any combinations with innovativeness, proactiveness and intentions. At the same time, CFA was conducted for each of the first-order latent constructs, which did not register any issues: innovativeness, proactiveness and intentions. The correlation values of each variable with the latent construct were high and the model fit was good as well. Furthermore, one questionnaire item for the measurement of innovativeness and one questionnaire item (out of four total in each) for proactiveness were excluded. It has been proven that even with three items for dimension, the questionnaire can still maintain statistical authenticity (Cook et al. 1981). If risk-taking should not be included in the questionnaire to measure entrepreneurial competences-even with a oneitem reduction each for innovativeness and proactiveness - the questionnaire is still statistically authentic.

${ }^{2} \mathrm{~A}$ value of the RMSEA of about 0.05 or less would indicate a close fit of the model in relation to the degrees of freedom. The requirement of exact fit corresponds to RMSEA $=0.0$. A value of about 0.08 or less for the RMSEA would indicate a reasonable error of approximation, and one would not want to employ a model with a RMSEA greater than 0.1 . GFI is less than or equal to 1 . A value of 1 indicates a perfect fit. It is acceptable when GFI $>0.9$ The AGFI (adjusted goodness of fit index) considers the degrees of freedom available for testing the model. The AGFI is bounded above by one, which indicates a perfect fit. It is not, however, bounded below by zero, as the GFI is. It is acceptable when AGFI $>0.9$. CFI falls in the range from 0 to 1 . CFI values close to 1 indicate a very good fit.
} 


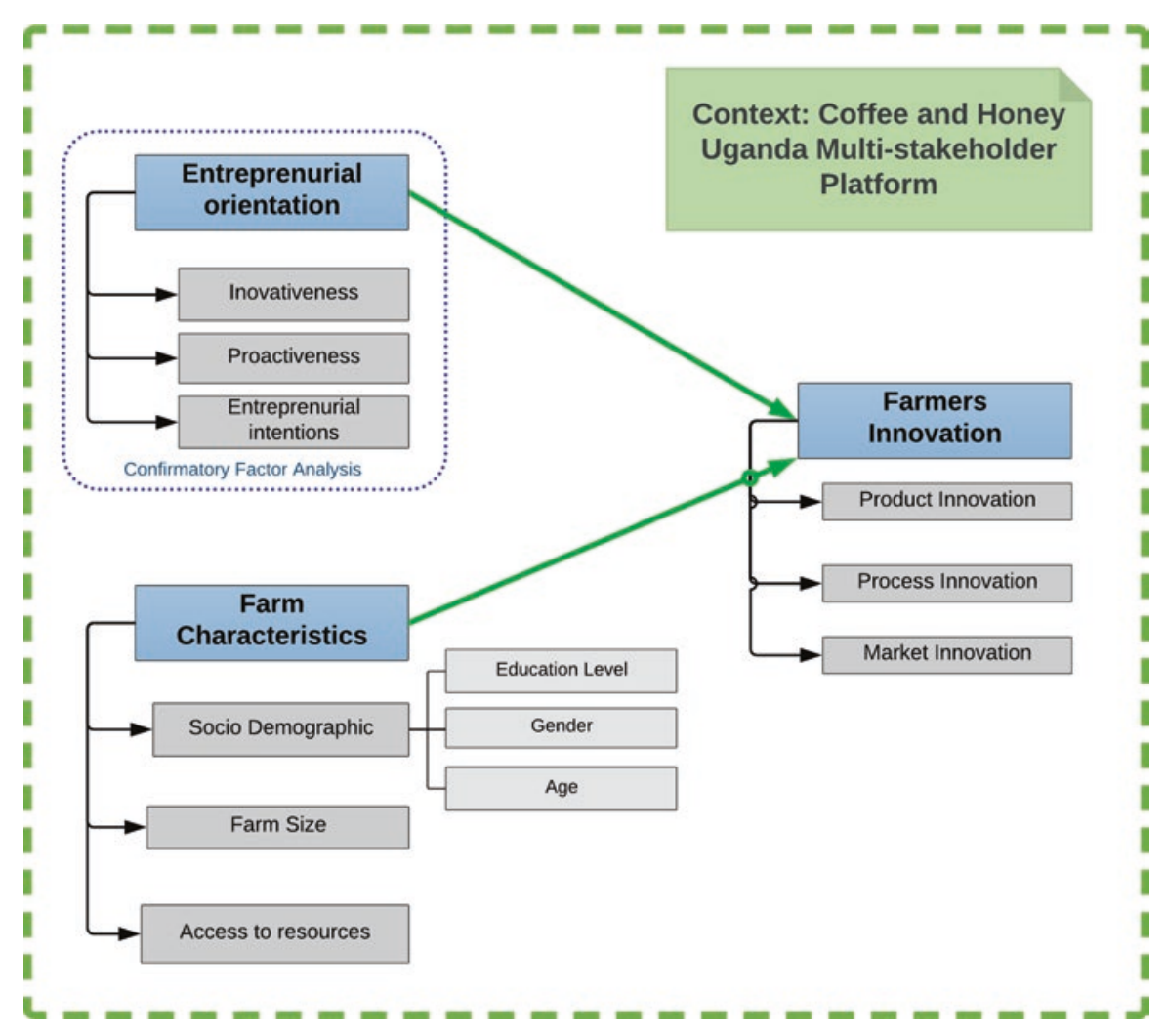

Fig. 17.1 Analyzed relationship between variables

level, farm size and access to resources have a significant effect on all forms of agricultural innovation (product, process and market). Entrepreneurial orientation variables showed no significant impact. At this stage of the analysis all variables were included in the tested model, which was too many variables given the relatively limited sample $(n=152)$. To decrease the number of variables, we separately included each dimension of entrepreneurial orientation (innovativeness, proactiveness, risk-taking and entrepreneurial intentions) together with all of the farm characteristics. After running this second set of regression models, it was found that education has a significant impact on process innovation. Similarly, when entrepreneurial proactiveness or entrepreneurial intentions are taken into account, a higher education level has a significant effect on process innovation (see Appendix 1). Simply put, farmers who engage in process innovation in their coffee and honey value chains do so not because of their proactiveness, innovativeness or intentions, but rather because of their higher education levels.

When we exclude education from the regression models, however, entrepreneurial orientation showed a positive effect on farmers' innovations. In particular, when farmers have higher entrepreneurial innovativeness, smaller farms have a more pos- 
Table 17.2 Model summary and significance of interaction between entrepreneurial innovativeness, farm size and process innovation

\begin{tabular}{|c|c|c|c|c|c|c|c|c|}
\hline \multicolumn{2}{|c|}{ Model } & \multicolumn{2}{|c|}{$\begin{array}{l}\text { Unstandardized } \\
\text { coefficients }\end{array}$} & \multirow{2}{*}{\begin{tabular}{|l|}
$\begin{array}{l}\text { Standardized } \\
\text { coefficients }\end{array}$ \\
Beta \\
\end{tabular}} & \multirow[t]{2}{*}{$\mathrm{t}$} & \multirow[t]{2}{*}{ Sig } & \multicolumn{2}{|c|}{$\begin{array}{l}\text { Collinearity } \\
\text { statistics }\end{array}$} \\
\hline & & B & \begin{tabular}{|l|} 
Std. \\
error
\end{tabular} & & & & Tolerance & VIF \\
\hline \multirow[t]{3}{*}{1} & Constant & 1.860 & 0.966 & & 1.926 & 0.056 & & \\
\hline & $\begin{array}{l}\text { Entr. } \\
\text { innovativeness }\end{array}$ & 0.121 & 0.067 & 0.146 & 1.797 & 0.074 & 0.999 & 1.001 \\
\hline & Farm size & 0.118 & 0.199 & 0.048 & 0.590 & 0.556 & 0.999 & 1.001 \\
\hline \multirow[t]{4}{*}{2} & Constant & -4.292 & 2.773 & & -1.548 & 0.124 & & \\
\hline & $\begin{array}{l}\text { Entr. } \\
\text { innovativeness }\end{array}$ & 0.573 & 0.202 & 0.688 & 2.830 & 0.005 & 0.107 & 9.304 \\
\hline & Farm size & 5.276 & 2.192 & 2.145 & 2.406 & 0.017 & 0.008 & 124.936 \\
\hline & $\begin{array}{l}\text { Farm size - entr. } \\
\text { innovativeness }\end{array}$ & -0.379 & 0.160 & -2.162 & -2.362 & 0.019 & 0.008 & 131.673 \\
\hline
\end{tabular}

Table 17.3 Model summary and significance of interaction between entrepreneurial proactiveness, farm size and process innovation

\begin{tabular}{|c|c|c|c|c|c|c|c|c|}
\hline \multirow{2}{*}{\multicolumn{2}{|c|}{ Model }} & \multicolumn{2}{|c|}{$\begin{array}{l}\text { Unstandardized } \\
\text { coefficients }\end{array}$} & \multirow{2}{*}{$\begin{array}{l}\text { Standardized } \\
\text { coefficients } \\
\text { Beta }\end{array}$} & \multirow[t]{2}{*}{$\mathrm{t}$} & \multirow[t]{2}{*}{ Sig } & \multicolumn{2}{|c|}{$\begin{array}{l}\text { Collinearity } \\
\text { statistics }\end{array}$} \\
\hline & & B & $\begin{array}{l}\text { Std. } \\
\text { error }\end{array}$ & & & & Tolerance & VIF \\
\hline \multirow[t]{3}{*}{1} & Constant & 10.321 & 2.308 & & 4.472 & 0.000 & & \\
\hline & Farm size & 0.730 & 0.578 & 0.102 & 1.263 & 0.209 & 1.000 & 1.000 \\
\hline & $\begin{array}{l}\text { Entr. } \\
\text { proactiveness }\end{array}$ & 0.220 & 0.169 & 0.105 & 1.301 & 0.195 & 1.000 & 1.000 \\
\hline \multirow[t]{4}{*}{2} & Constant & 23.497 & 5.909 & & 3.977 & 0.000 & & \\
\hline & Farm size & -9.628 & 4.325 & -1.350 & -2.226 & 0.028 & 0.017 & 57.809 \\
\hline & $\begin{array}{l}\text { Entr. } \\
\text { proactiveness }\end{array}$ & -0.821 & 0.462 & -0.393 & -1.777 & 0.078 & 0.130 & 7.702 \\
\hline & $\begin{array}{l}\text { Farm size - entr. } \\
\text { proactiveness }\end{array}$ & 0.818 & 0.339 & 1.547 & 2.416 & 0.017 & 0.016 & 64.441 \\
\hline
\end{tabular}

itive effect on all forms of agricultural innovation. Specifically, if the interaction between farm size and entrepreneurial innovativeness increases, process innovation decreases (see Table 17.2).

This means that farmers with a smaller farm size and higher innovativeness were the most likely to engage in all forms of agricultural innovation. Furthermore, the interaction between farmer proactiveness and farm size has a positive effect on all forms of farmer innovation. Specifically, if the interaction effect among farm size and entrepreneurial proactiveness increases, the computed variable of process innovation increases (Sig. 0.18) (see Table 17.3). This means that proactive farmers with a larger farm size are the most likely to engage in all forms of agricultural innovations. Third, contrary to our initial hypothesis, farm size has a negative effect on innovation. In particular, if the size of the farm increases, process innovation 
decreases (Appendix 2). This means that larger farms (with more than 20 beehives or more than 1 acre of coffee-cultivated land) are generally less inclined than smaller farms to innovate their processes. Finally, when access to farm input resources increases, process innovation increases as well, when entrepreneurial competencies are also considered (Appendix 3).

No other variable - not entrepreneurial orientation or farm characteristicsinfluences process innovations as much as a farmer's education level, a finding that has been demonstrated frequently in many other contexts (e.g., Thangata and Alavalapati 2003). In Uganda, however, relatively few farmers attain high levels of education, so it is important to evaluate the findings with education level taken out of the equation. Results suggested that farmers with smaller farm size and higher access to resources have significantly higher levels of agricultural innovation. This finding on farm size is somewhat surprising because it contrasts with a wide literature suggesting that larger farms engage more often in innovations (Adesina and Baidu-Forson 1995; Weir and Knight 2004). To better understand these results, we further analyzed the interaction effect of these farm characteristics and entrepreneurial orientation on innovation. We found:

- The higher farmers' innovativeness is, the stronger the negative effect of farm size on their innovations. This may suggest that smaller farmers would be the most reactive in taking up new product, process and market innovations when they become more innovative.

- The higher farmers' proactiveness is, the stronger is the positive effect of farm size on their innovations. This may suggest that larger farmers would be the most reactive in taking up new product, process and market innovations when they become more proactive.

These results confirm that factors such as education levels, farm size and access to resources are key factors shaping the triggering and scaling of agricultural innovations, including those related to CSA practices.

A couple of methodological cautions are in order. First, by testing the measurement model through the CFA, we found that the measures of risk-taking as a dimension of entrepreneurial orientation did not fit the data in the Ugandan context. This means that - in contrast to Lai et al. (2017a) in the Philippines-the farmers in this Ugandan survey did not understand how the questionnaire items on risk-taking together corresponded to one concept. More significantly, this signals that risktaking may not be a suitable or desirable dimension of entrepreneurial orientation in a farm context afflicted by market, social and environmental shocks. Given the limited sample size, though, it is worth conducting further tests on the risk-taking in other context before recommending to definitely drop this dimension in similar study contexts.

Second, in our database, multicollinearity among variables is high (meaning that the dimensions of entrepreneurial orientation are highly correlated with each other and with some farm characteristics) and sample size is relatively small $(\mathrm{n}=152)$. This created statistical problems that forced us to build multiple smaller regression models to analyze all the variables of interest. If future research allows the collec- 
tion of a larger sample, multivariate statistics may offer a valid alternative to the use of linear regressions. Furthermore, to avoid desirability bias (i.e., farmers trying to give perceived-as-desirable answers to the interviewer), future research may combine survey questions with direct participant observation of farmers' innovative and proactive actions over time, as well as their interactions with stakeholders in their environments.

\subsection{Implications for Development}

Our findings suggest that there are opportunities for development efforts to promote innovation among farmers. It is important to note that current psychological theories see entrepreneurial orientation not as a personality trait (Rauch and Frese 2007) fixed early in life but as a mindset that can develop over time-that can, in other words, be learned (Baum et al. 2014; Campos et al. 2017). At least two learnable dimensions of farmers' entrepreneurial orientation-proactiveness and innovativeness - may play a role in the adoption and scaling of agricultural innovations when tailored to certain types of farmers (York and Venkataraman 2010; Bruton et al. 2013). The development of a proactive and innovative mindset can be encouraged through workshops and other training activities for farmers. MSPs can thereby act as spaces for engaging in entrepreneurship training and thus supporting the development of entrepreneurial ecosystems (Bruton and Ahlstrom 2003; Dentoni and Klerkx 2015; Seuneke et al. 2013). In particular, smallholder farmers may benefit from tailored trainings on innovativeness, while larger farmers would benefit from capacity-building activities focusing on proactiveness. Therefore, if confirmed on studies at a larger scale, these findings suggest that training focused on shifting the mindsets of farmers can lay the groundwork for agricultural innovation.

\section{Appendix 1}

\begin{tabular}{|c|c|c|c|c|c|c|c|c|}
\hline \multicolumn{9}{|c|}{ Coefficients - process innovation } \\
\hline \multirow{2}{*}{\multicolumn{2}{|c|}{ Model }} & \multicolumn{2}{|c|}{$\begin{array}{l}\text { Unstandardized } \\
\text { coefficients }\end{array}$} & \multirow{2}{*}{\begin{tabular}{|l} 
Standardized \\
coefficients \\
Beta
\end{tabular}} & \multirow[t]{2}{*}{$\mathrm{t}$} & \multirow[t]{2}{*}{ Sig } & \multicolumn{2}{|c|}{$\begin{array}{l}\text { Collinearity } \\
\text { statistics }\end{array}$} \\
\hline & & B & $\begin{array}{l}\text { Std. } \\
\text { error }\end{array}$ & & & & Tolerance & VIF \\
\hline \multirow[t]{3}{*}{1} & Constant & 1.967 & 0.765 & & 2.571 & 0.011 & & \\
\hline & Education level & 0.280 & 0.127 & 0.179 & 2.202 & 0.029 & 0.966 & 1.035 \\
\hline & Entr. [roactiveness & 0.076 & 0.058 & 0.106 & 1.301 & 0.195 & 0.966 & 1.035 \\
\hline
\end{tabular}




\begin{tabular}{l|l|l|l|l|l|l|l|l}
\hline 2 & Constant & 4.898 & 2.810 & & 1.743 & 0.083 & & \\
\hline Education level & -0.978 & 1.167 & -0.624 & -0.838 & 0.404 & 0.011 & 87.238 \\
\hline Entr. proactiveness & -0.152 & 0.218 & -0.211 & -0.696 & 0.488 & 0.069 & 14.447 \\
\hline $\begin{array}{l}\text { Education } \\
\text { level - entr. } \\
\text { proactiveness }\end{array}$ & 0.097 & 0.090 & 0.920 & 1.084 & $\mathbf{0 . 2 8 0}$ & 0.009 & 113.171 \\
\hline
\end{tabular}

Coefficients - process innovation

\begin{tabular}{l|l|l|l|l|l|l|l|l}
\hline \multirow{2}{*}{ Model } & \multicolumn{2}{|l|}{$\begin{array}{l}\text { Unstandardized } \\
\text { coefficients }\end{array}$} & $\begin{array}{l}\text { Standardized } \\
\text { coefficients }\end{array}$ & t & Sig & \multicolumn{2}{l}{$\begin{array}{l}\text { Collinearity } \\
\text { statistics }\end{array}$} \\
\cline { 2 - 8 } & B & $\begin{array}{l}\text { Std. } \\
\text { error }\end{array}$ & Beta & & & Tolerance & VIF \\
\hline 1 & Constant & 3.091 & 0.822 & & 3.760 & 0.000 & & \\
\hline & Education level & 0.322 & 0.131 & 0.205 & 2.462 & 0.015 & 0.927 & 1.079 \\
\hline & Entr. intentions & -0.015 & 0.048 & -0.026 & -0.307 & 0.759 & 0.927 & 1.079 \\
\hline 2 & Constant & 2.318 & 2.769 & & 0.837 & 0.404 & & \\
\hline & Education level & 0.637 & 1.087 & 0.407 & 0.586 & 0.559 & 0.013 & 74.265 \\
\hline Entr. intentions & 0.030 & 0.160 & 0.052 & 0.186 & 0.852 & 0.085 & 11.800 \\
\hline $\begin{array}{l}\text { Education } \\
\text { Level - entr. } \\
\text { Intentions }\end{array}$ & -0.018 & 0.062 & -0.236 & -0.293 & $\mathbf{0 . 7 7 0}$ & 0.010 & 100.066 \\
\hline
\end{tabular}

Dependent Variable: I have improved my production practices because other actors in my value chain suggested it to me in the past 5 years

\section{Appendix 2}

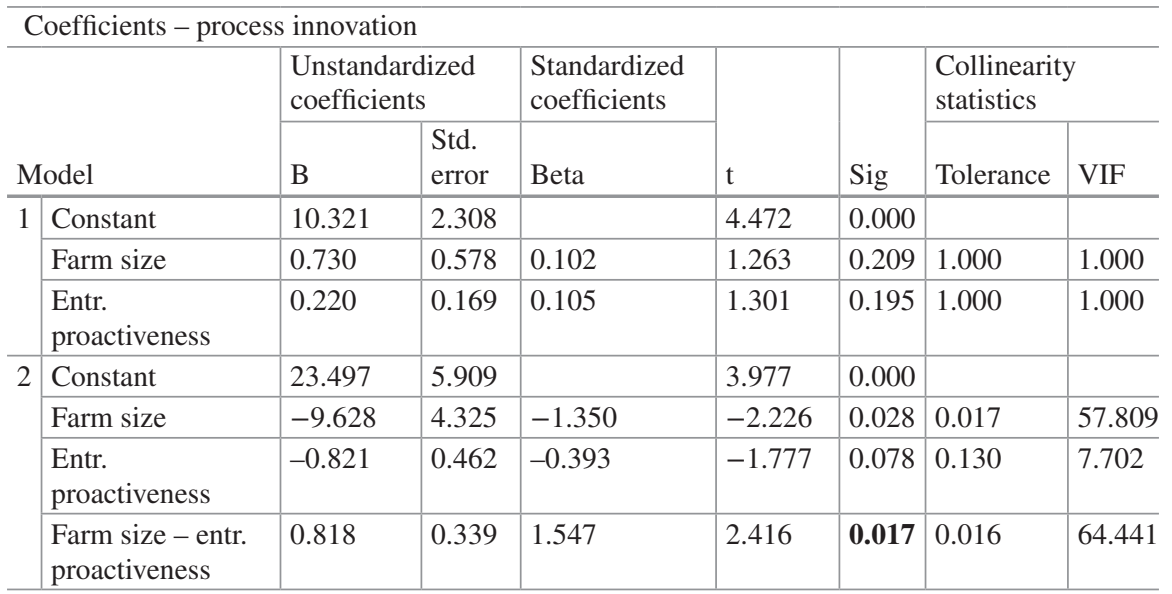

Dependent Variable: innovation 


\section{Appendix 3}

\begin{tabular}{|c|c|c|c|c|c|c|c|c|}
\hline \multicolumn{9}{|c|}{ Coefficients - process innovation } \\
\hline \multirow{2}{*}{\multicolumn{2}{|c|}{ Model }} & \multicolumn{2}{|c|}{$\begin{array}{l}\text { Unstandardized } \\
\text { coefficients }\end{array}$} & \multirow{2}{*}{$\begin{array}{l}\text { Standardized } \\
\text { coefficients }\end{array}$} & \multirow[b]{2}{*}{$\mathrm{t}$} & \multirow[b]{2}{*}{ Sig } & \multicolumn{2}{|c|}{\begin{tabular}{|l} 
Collinearity \\
statistics
\end{tabular}} \\
\hline & & \multirow{2}{*}{\begin{tabular}{|l} 
B \\
2.812
\end{tabular}} & \multirow{2}{*}{\begin{tabular}{|l|}
$\begin{array}{l}\text { Std. } \\
\text { error }\end{array}$ \\
0.826 \\
\end{tabular}} & & & & \multirow[t]{2}{*}{ Tolerance } & \multirow[t]{2}{*}{ VIF } \\
\hline 1 & Constant & & & & 3.405 & 0.001 & & \\
\hline & $\begin{array}{l}\text { Access to } \\
\text { resources }\end{array}$ & 0.075 & 0.025 & 0.250 & 3.064 & 0.003 & 0.949 & 1.054 \\
\hline & Entr. intentions & -0.015 & 0.047 & -0.027 & -0.327 & 0.744 & 0.949 & 1.054 \\
\hline \multirow[t]{4}{*}{2} & Constant & 3.460 & 2.928 & & 1.182 & 0.239 & & \\
\hline & $\begin{array}{l}\text { Access to } \\
\text { resources }\end{array}$ & 0.031 & 0.194 & 0.102 & 0.158 & 0.874 & 0.015 & 65.504 \\
\hline & Entr. intentions & -0.054 & 0.175 & -0.094 & -0.310 & 0.757 & 0.069 & 14.510 \\
\hline & $\begin{array}{l}\text { Access to } \\
\text { resources - Entr. } \\
\text { Intentions }\end{array}$ & 0.003 & 0.011 & 0.177 & 0.231 & 0.818 & 0.011 & 92.249 \\
\hline
\end{tabular}

Dependent Variable: I have improved my production practices because other actors in my value chain suggested it to me in the past 5 years

\section{References}

Adesina AA, Baidu-Forson J (1995) Farmers' perceptions and adoption of new agricultural technology: evidence from analysis in Burkina Faso and Guinea, West Africa. Agric Econ 13(1):1-9

Baum JR, Frese M, Baron RA (2014) The psychology of entrepreneurship. Psychology Press, Mahwah

Bomuhangi A, Namaalwa J, Nabanoga G (2016) Natural resources policy environment in Uganda, implication for gendered adaptation to climate changes. Environ Sci Ind J 12(10):117

Bruton GD, Ahlstrom D (2003) An institutional view of China's venture capital industry: explaining the differences between China and the West. J Bus Ventur 18(2):233-259

Bruton GD, Ahlstrom D, Obloj K (2008) Entrepreneurship in emerging economies: the research go in the future. Entrep Theory Pract 32(January):1-14

Bruton GD, Ketchen DJ, Ireland RD (2013) Entrepreneurship as a solution to poverty. J Bus Ventur 28(6):683-689. Available at:. https://doi.org/10.1016/j.jbusvent.2013.05.002

Campos $\mathrm{F}$ et al (2017) Teaching personal initiative beats traditional training in boosting small business in West Africa. Science 357(6357):1287-1290

Cook, J. D., Hepworth, S. J., Wall, T. D., \& Warr, P. B. (1981). The experience of work: A compendium and review of 249 measures and their use: Academic Press London

Dentoni D, Klerkx L (2015) Co-managing public research in Australian fisheries through convergence-divergence processes. Mar Policy 60:259-271 
George G et al (2016) Social structure, reasonable gain, and entrepreneurship in Africa. Strateg Manag J 37(6):1118-1131

Harrington D (2009) Confirmatory factor analysis. Oxford University Press, Oxford

Johne A (1999) Successful market innovation. Eur J Innov Manag 2(1):6-11

Khavul S, Bruton GD (2013) Harnessing Innovation for Change: Sustainability and Poverty in Developing Countries. J Manag Stud 50:285-306. https://doi.org/10.111 $1 / \mathrm{j} .1467-6486.2012 .01067$

Kilelu CW, Klerkx L, Leeuwis C (2013) Unravelling the role of innovation platforms in supporting co-evolution of innovation: contributions and tensions in a smallholder dairy development programme. Agric Syst 118:65-77 Available at: http://linkinghub.elsevier.com/retrieve/pii/ S0308521X1300036X [Accessed 17 July 2014]

Krauss SI et al (2005) Entrepreneurial orientation: a psychological model of success among southern African small business owners. Eur J Work Organ Psy 14(3):315-344

Lai C Chan C, et al. (2017a) 5 measuring youth entrepreneurship attributes: the case of an out-ofschool youth training program in Mindanao, Philippines. Enabling agri-entrepreneurship and innovation: empirical evidence and solutions for conflict regions and transitioning economies, p 72

Lai C, Dentoni D et al (2017b) Adapting the measurement of youth entrepreneurship potential in a marginalised context: the case of Mindanao, Philippines. J Int Bus Entrep Dev 10(3):273-297

Lans T, Seuneke P, Klerkx L (2013) Agricultural entrepreneurship. In Encyclopedia of creativity, invention, innovation and entrepreneurship (pp. 44-49). Springer, New York, NY

Lipper L et al (2014) Climate-smart agriculture for food security. Nat Clim Chang 4(12):1068-1072

Naudé W (2010) Entrepreneurship, developing countries, and development economics: new approaches and insights. Small Bus Econ 34(1):1

Rauch A, Frese M (2007) Let's put the person back into entrepreneurship research: A meta-analysis on the relationship between business owners' personality traits, business creation, and success. Eur J Work Organ Psy 16(4):353-385

Sabiiti G et al (2016) Empirical relationships between banana yields and climate variability over Uganda. J Environ Agric Sci 7:3-13

Schut $\mathrm{M}$ et al (2015) Innovation platforms: experiences with their institutional embedding in agricultural research for development. Exp Agric 44:37 Available at: internal-pdf://84.152.52.160/ Schut-2015-INNOVATION PLATFORMS_EXPERIENCES W.pdf

Seuneke P, Lans T, Wiskerke JSC (2013) Moving beyond entrepreneurial skills: key factors driving entrepreneurial learning in multifunctional agriculture. J Rural Stud 32:208-219. Available at:. https://doi.org/10.1016/j.jrurstud.2013.06.001

Shane S, Venkataraman S (2000) The promise of entrepreneurship as a field of research. Acad Manag Rev 25(1):217-226

Thangata PH, Alavalapati JRR (2003) Agroforestry adoption in southern Malawi: the case of mixed intercropping of Gliricidia sepium and maize. Agric Syst 78(1):57-71

Weir S, Knight J (2004) Externality effects of education: dynamics of the adoption and diffusion of an innovation in rural Ethiopia. Econ Dev Cult Chang 53(1):93-113

Wu B, Pretty J (2004) Social connectedness in marginal rural China: the case of farmer innovation circles in Zhidan, north Shaanxi. Agric Hum Values 21(1):81-92

Yang, Li (2013) An empirical research on farmer innovation in agriculture industrial clusters. International conference on the modern development of humanities and social science. Hong Kong.

York JG, Venkataraman S (2010) The entrepreneur-environment nexus: uncertainty, innovation, and allocation. J Bus Ventur 25(5):449-463. Available at:. https://doi.org/10.1016/j. jbusvent.2009.07.007 
Zilberman D et al (2018) Climate smart agriculture. Building resilience to climate change. Volume 52. B. Branca, LL, McCarthy N, Zilberman D, Solomon A, Giacomo, ed., Natural resource management and policy. Available at: http://link.springer.com/10.1007/978-3-319-61194-5

Open Access This chapter is licensed under the terms of the Creative Commons Attribution 4.0 International License (http://creativecommons.org/licenses/by/4.0/), which permits use, sharing, adaptation, distribution and reproduction in any medium or format, as long as you give appropriate credit to the original author(s) and the source, provide a link to the Creative Commons license and indicate if changes were made.

The images or other third party material in this chapter are included in the chapter's Creative Commons license, unless indicated otherwise in a credit line to the material. If material is not included in the chapter's Creative Commons license and your intended use is not permitted by statutory regulation or exceeds the permitted use, you will need to obtain permission directly from the copyright holder.

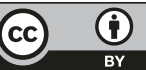

